\title{
Impact of Implementation of Current Land Reform Policy in Nepal
}

\author{
Damaru Ballabha Paudel ${ }^{1 *}$ and Katsuhiro Saito ${ }^{2}$
}

The objective of this study is to evaluate the potential impact of implementation of current land reform policy in Nepal. Using SAM framework, we study the impact of alternative policies of land reform on GDP, households' income, production of different sectors, government revenues, savings, foreign exchange and employment. We found that redistributive reform increases income of poor households and reduces inequality. Productivity augmenting reform has more impact on economy as it increases productivity of all sectors including income of all households keeping inequality unchanged. Furthermore, implementing both reforms simultaneously produce more impact by gaining both equity and efficiency.

Key words : land reform, poverty, social accounting matrix (SAM)

\section{Introduction}

Low economic growth and high prevalence of poverty are the inherent features of Nepalese economy. The economic growth was about $4 \%$ for last decade (Ministry of Finance [7]) and the absolute poverty in 2011 was $25.2 \%$ (Central Bureau of Statistic [4]). As average productivity of cereals crops is 2.85 metric tons per hectors (The World Bank [13]), it is the lowest in South Asian Region. Aditionally, only $17 \%$ of the country's total land is arable and ownership distribution of land is skewed. The landless do not have land for cultivation whereas some of the land with large landlords is left fallow. The visible inequality in land distribution is one of the causes of low productivity in Nepal because those who have farming skills do not have enough land and those who have land do not have farming skill or no necessity of farming (Adhikari and Bjondal [1]). This kind of adverse situation in land is causing a vocal demand for land reform. However, land reform was started in Nepal in 1951 and comprehensive land reform law was commenced in 1964, the progress of land reform is very slow. Many studies (Regmi [12]; Community Self-Reliance Centre, [5]; Adhikari [2]; Adhikari and Bjorndal [1] etc.) evaluated the land reform process of Nepal as unsuccessful so far and indicated the need for successful land reform. Moreover, land reform issues are live issues in many

\footnotetext{
${ }^{1}$ Ministry of Finance, Government of Nepal

${ }^{2}$ The University of Tokyo

Corresponding author*:dbpaudel@hotmail.com
}

developing countries including Nepal (Lipton [6]) and they are more serious now than decades ago because land reform has not come to a logical end and the story of poverty and inequality is much more complex today. Therefore, we, in this paper, evaluate the impact of land reform in Nepal using social accounting matrix (SAM) framework. If the current land ceiling provisions were implemented strictly what would be the impact of land reform on income distribution of households; and in the whole economy; is the main research purpose in this study. Instead of estimating the actual impact of land reform, this paper shows the potential impacts.

Thus, to fulfill this research purpose, we make different three scenarios for land reform and see the effect of reform in production, households income and the whole economy. Here, we intend to see the micro-simulation effect of land reform on macro-economy of Nepal, which is also the distinct feature of this study. To the best of our knowledge, this type of simulation study is new in literature.

\section{Nepal SAM 2010/11 and Its Features}

In this paper, we use Nepal SAM 2010/11 (Paudel and Saito [11]) as main source of data. In this SAM, activities and commodities are divided into 36 sectors which include 12 sectors for agriculture, 11 sectors for manufacturing and rest 13 sectors for construction, trading, services and others. Similarly, three primary factor accounts (land, labor, capital) and 24 household accounts, four government accounts income tax, value added tax, import tariff, other government 
Table 1. Source-wise Household Income (in \%) \begin{tabular}{lllll}
\hline Households Labor Capital Land Firm Government & Foreign Exchange & Total \\
\hline
\end{tabular} \begin{tabular}{llllllll}
\hline Rural Households & 23.37 & 5.20 & 13.37 & 25.05 & 3.24 & 29.77 & 100
\end{tabular} \begin{tabular}{llllllll} 
Urban Households & 37.83 & 9.07 & 12.80 & 23.95 & 2.16 & 14.18 & 100 \\
\hline
\end{tabular} Source: Paudel and Saito [11] activities; one enterprise account, one capital account, and one rest of the world account.

Table 1 shows the source-wise household income taken from Nepal SAM 2010/11. Average share of labor income is higher in urban households (37.83\%) than rural $(23.37 \%)$. This is because people work in formal sector in urban region and their salary is higher. Similarly, urban households have average share of capital rental income $(9.07 \%)$ higher than rural households do (5.20\%). However, share of other sources of income (land rental income, business enterprise income, government transfer income and

Table 2. Household Expenditure Category (in \%)

\begin{tabular}{lcccc}
\hline Households & Commodities & Government & Capital account & Total \\
\hline Rural Households & 90.54 & 0.45 & 9.02 & 100 \\
Urban Households & 74.79 & 4.42 & 20.79 & 100 \\
\hline
\end{tabular}

Source: Paudel and Saito [11]

foreign exchange income or remittance income) is higher in rural households.

Similarly, table 2 shows household expenditure category of rural and urban households. Average share of consumption expenditure on commodities is higher in rural households $(90.54 \%)$ than urban $(74.79 \%)$. However, share of taxes to government is higher in urban households $(4.42 \%)$ than rural $(0.45 \%)$. Similarly, share of saving is higher in urban households $(20.79 \%)$ than rural $(9.02 \%)$.

\section{Impacts of Land Reform}

In case of Nepal, the Land Related Act 1964 (Nepal Law Commission [8]) is the main law for land reform. It is amended many times and the mentionable amendment is the Fifth Amendment. The Fifth Amendment to the Land Related Act 1964 was done in 2002 (hereafter, FALRA 2002) that drastically reduced the land ceiling in the country aiming to use land in the most productive way. According to FALRA 2002, land ceiling was reduced by $60 \%$ in Terai (from 18.40 hectares to 7.45 hectares), $51 \%$ in Kathmandu Valley (from 3.10 hectares to 1.52 hectares) and $22 \%$ in all other regions (from 4.90 hectares to 3.81 hectares) including both agricultural and homestead land. The law made provision of redistributive land reform in favor of poor farmers but the law could not come into action due to many barriers from opposing forces including deficiency of proper implementation of policy. Land reform in Nepal has always been criticized for lack of will power to implement it (Regmi [12]). FALRA 2002 also was not properly implemented indicating failed reform on land. The scenario of land distribution would be different if the land ceiling policy of FALRA 2002 were properly implemented (Paudel and Saito [9]).

Moreover, having more household land shows a higher status in society, more influence in politics and it also helps as collateral for borrowing credit. As immoveable assets, it has additional intrinsic value and more security. In order to see the relationship between household own land size and social

\begin{tabular}{|c|c|c|c|c|c|c|c|}
\hline \multirow{2}{*}{ Land Category } & \multirow{2}{*}{ Region } & \multicolumn{6}{|c|}{ Housshold Land Size (in ha) } \\
\hline & & Before Reform & After Reform & $\%$ change & Before Reform & After Reform & \% change \\
\hline \multirow{3}{*}{ Large } & Terai & 16.02 & 7.45 & -53.48 & $85,150.67$ & $77,781.00$ & -8.65 \\
\hline & Kathmandu Valley & 2.26 & 1.52 & -32.86 & $55,069.71$ & $52,571.70$ & -4.54 \\
\hline & Other Regions & 6.41 & 3.81 & -37.97 & $29,842.11$ & $28,083.65$ & -5.89 \\
\hline \multirow{3}{*}{ Marginal } & Terai & 0.15 & 0.22 & 52.61 & $20,959.91$ & $22,651.56$ & 8.07 \\
\hline & Kathmandu Valley & 0.05 & 0.06 & 33.23 & $26,989.25$ & $34,491.56$ & 27.8 \\
\hline & Other Regions & 0.08 & 0.12 & 47.49 & $19,496.42$ & $20,788.80$ & 6.63 \\
\hline \multirow{3}{*}{ Landless } & Terai & 0.02 & 0.12 & 379.89 & $14,271.02$ & $20,152.00$ & 41.21 \\
\hline & Kathmandu Valley & 0.02 & 0.05 & 165.61 & $22,723.42$ & $32,264.37$ & 41.99 \\
\hline & Other Regions & 0.03 & 0.08 & 230.34 & $15,332.61$ & $21,335.43$ & 39.15 \\
\hline
\end{tabular}
welfare; Paudel and Saito [9] estimated consumption function and found that transfer of beyond ceiling land from large holdings to marginal and landless will not only change the structure of land ownership but also the consumption pattern in Nepalese economy. The mean per capita consumption of large households will decrease but percapita consumption of landless and marginal households increase substantially. Consequently, using household level survey data (Central Bureau of Statistics [3]), they estimated that how implementation of land reform affects percapita consumption of households (see table 3 ).

Likewise, Paudel and Saito [10] also estimated stochastic frontier function for Nepalese agriculture and found that household farms are operating less than frontier and inefficiency sources are common. Besides, the gap between frontier and actual production is $30 \%$ and mean technical efficiency scores vary widely between household land sizes and regions. According to them, land reform will transfer land from landlords to the landless and marginal farmers who have hard working practices. If land reform policies were implemented and inefficiencies were eliminated, the agricultural productivity would rise even using the same level of inputs. Furthermore, utilization of unused land and consolidation of fragmented land could reduce at least $10 \%$ of inefficiency in Nepalese agriculture. Therefore, for simulation purpose, we assume 10\% productivity can be raised by eliminating some of the inefficiencies. We term this type of reform as productivity augmenting reform in this study. 


\section{Analytical Framework}

\section{1) Model}

In order to study the impact of land reform, we use SAM framework. A SAM is a square matrix which represents an economy at a point of time and is very useful for identifying the impact of a policy (for detail, see Sadoulet and de Janvry [13]). The matrix multiplier model is given as:

$$
\begin{aligned}
& X=A X+F \\
& X=(I-A)^{-1} F \\
& X=M F
\end{aligned}
$$

Where, $\mathrm{X}$ is vector of total income or expenditure of the endogenous accounts, $\mathrm{F}$ is vector sum of the expenditures of the exogenous accounts, $\mathrm{L}$ is column vector of the income of exogenous accounts, $A$ is a square matrix (nxn) of coefficients of endogenous accounts, B is a rectangular matrix (mxn) of coefficients with exogenous accounts as rows and endogenous accounts as column. The matrix of Multipliers and $\Delta \mathrm{F}$ being the vector of shocks, the vector of impacts $(\Delta \mathrm{X})$ is given as:

$$
\begin{aligned}
\mathrm{M} & =(\mathrm{I}-\mathrm{A})^{-1} \\
\Delta \mathrm{X} & =(\mathrm{I}-\mathrm{A})^{-1} \Delta \mathrm{F}
\end{aligned}
$$

Similarly, induced impacts or the leakages are given as:

$$
\triangle \mathrm{L}=\mathrm{B} \triangle \mathrm{X}
$$

In this model, we take activities, commodities, factors, enterprises and households as endogenous accounts and government accounts, capital accounts, rest of the world accounts as exogenous accounts. Moreover, in this model we treat land endowment as policy variable (as exogenous variable) while land input is one of the factors of production and endogenous variable. Land input is the total operated land in the economy while land endowment is total owned land. Land endowment also includes unused land such as left fallow land.

\section{2) Simulation Scenarios}

We set three scenarios to know the impacts of land reform in Nepalese economy. Simulation 1: Because of the implementation of current ceiling policy, i.e., FALRA 2002, the large households lose their beyond ceiling land but landless and marginal households will receive land. We simulate this change within the household categories in this scenario and see the direct and induced impacts of land reform. For this simulation, we assume that the households, which either gain or lose their income as the result of land reform, are exogenous. Simulation 2: We assume that if productivity-augmenting land reform were implemented, at least $10 \%$ productivity of agricultural sectors (crops productivity) would rise. Eliminating mainly two barriersutilizing the unused land and reducing land fragmentation would gain this productivity. In this simulation, we assume that crop production activities are exogenous; other activities are endogenous and production of exogenous activities increases by $10 \%$. Simulation 3: This simulation is the application of both the simulation 1 and simulation 2 simultaneously.

\section{Results and Discussions}

Table 4 shows the results of simulation of three scenarios. We found that in simulation 1 , the shock is the transfer of income from large to landless and marginal households as the result of implementation of ceiling policy. In this policy, agricultural production increases by $4.88 \%$ while non-agricultural production increases by $2.34 \%$ resulting total domestic production to be increased by $3.21 \%$. GDP increases by $3.49 \%$, urban income increases by $2.27 \%$ and rural income increases by $6.55 \%$ resulting increase in total household income by $4.95 \%$. As the leakages effects, government revenue increases by $2.39 \%$, saving increases by $2.64 \%$, foreign exchange increases by $2.49 \%$ and employment increases by $4.20 \%$ in Nepalese economy. Distributive reform has more impact on agricultural production and rural income than on non-agricultural production and urban income. This shows that distributive reform is pro-poor.

In simulation 2, the shock is the increase in agricultural crops production by $10 \%$. This type of policy has higher impact on macro-economy compared to distributive land reform. Agricultural production increases by $8.63 \%$ while non-agricultural production increases by $2.54 \%$ causing total domestic production and GDP to be increased by $4.61 \%$ and $5.11 \%$ respectively. In this policy simulation, both urban and rural income increase substantially by $4.34 \%$ and $5.62 \%$ respectively, this raises total household income by $5.14 \%$. As the result of leakage effects, government revenue increases by $3.27 \%$, saving increases by $5.07 \%$, foreign exchange increases by $2.53 \%$ and employment increases by $7.48 \%$. In SAM framework, productivity augmenting reform has higher impact than redistributive reform.

In simulation 3, agricultural production increases by $10.48 \%$ while non-agricultural production increases by $5.39 \%$ 


\begin{tabular}{|c|c|c|c|c|c|c|c|c|c|c|}
\hline \multirow{3}{*}{ Sectors } & \multirow{3}{*}{$\begin{array}{c}\text { Baseline } \\
\text { Values } \\
\text { (billions } \\
\text { Rupees) }\end{array}$} & \multirow{2}{*}{\multicolumn{3}{|c|}{$\begin{array}{r}\text { Simulation 1 } \\
\text { Change }\end{array}$}} & \multirow{2}{*}{\multicolumn{3}{|c|}{$\begin{array}{r}\text { Simulation 2 } \\
\text { Change } \\
\end{array}$}} & \multirow{2}{*}{\multicolumn{3}{|c|}{$\begin{array}{r}\text { Simulation } 3 \\
\text { Change }\end{array}$}} \\
\hline & & & & & & & & & & \\
\hline & & Shouk & Value & $\%$ & & Value & $\%$ & Shor & Value & $\%$ \\
\hline \multicolumn{11}{|l|}{ Direct Impacts } \\
\hline Agricultural Product & 722.44 & 0.00 & 35.28 & 4.88 & 49.27 & 62.36 & 8.63 & 49.27 & 75.69 & 10.48 \\
\hline Non-Agricultural Production & 1403.58 & 0.00 & 32.91 & 2.34 & 0.00 & 35.66 & 2.54 & 0.00 & 75.67 & 5.39 \\
\hline Total Domestic Production & 2126.03 & 0.00 & 68.19 & 3.21 & 49.27 & 98.02 & 4.61 & 49.27 & 151.36 & 7.12 \\
\hline Gross Do & 1374.95 & 0.00 & 47.96 & 3.49 & 41.91 & 70.24 & 5.11 & 41.91 & 103.85 & 7.55 \\
\hline Urban Household Income & 485.98 & 0.00 & 11.02 & 2.27 & 0.00 & 21.11 & 4.34 & 0.00 & 26.32 & 5.42 \\
\hline Rural Household Income & 819.99 & 36.74 & 53.68 & 6.55 & 0.00 & 46.07 & 5.62 & 36.74 & 76.59 & 9.34 \\
\hline Total Household Income & 1305.97 & 36.74 & 64.71 & 4.95 & 0.00 & 67.18 & 5.14 & 36.74 & 102.91 & 7.88 \\
\hline \multicolumn{11}{|l|}{ Induced Impacts (Leakages) } \\
\hline Government Revenues & 169.99 & 0.00 & 4.06 & 2.39 & 0.00 & 5.56 & 3.27 & 0.00 & 12.84 & 7.55 \\
\hline Savings & 518.28 & 0.00 & 13.71 & 2.64 & 0.00 & 26.29 & 5.07 & 0.00 & 34.92 & 6.74 \\
\hline Foreign Exchange & 448.25 & 0.00 & 11.17 & 2.49 & 0.00 & 11.33 & 2.53 & 0.00 & 29.88 & 6.67 \\
\hline Employment (in ${ }^{\circ} 000$ ) & 15091.85 & 0.00 & 634.36 & 4.20 & 0.00 & 1129.19 & 7.48 & 0.00 & 1353,17 & 8.97 \\
\hline
\end{tabular}

resulting total domestic production to rise by $7.12 \%$. The large amount of increase in agricultural production brings up the rise of GDP by $7.55 \%$. Similarly, urban income increase by $5.42 \%$ and rural income increases by $9.34 \%$ with $7.88 \%$ rise in total household income. The induced impacts of this policy alternative are increase in government revenue by $7.55 \%$, increase in saving by $6.74 \%$, increase in foreign exchange by $6.67 \%$ and increase in employment by $8.97 \%$. Simulation 3 is the policy option in which both types of reforms are used

\begin{tabular}{|c|c|c|c|c|c|c|c|c|c|c|}
\hline \multirow{3}{*}{ S.N. Sectors } & \multirow{3}{*}{$\begin{array}{l}\text { Baseline } \\
\text { Values } \\
\text { (Billions } \\
\text { Runeesc) }\end{array}$} & \multicolumn{3}{|c|}{ Simulation 1} & \multicolumn{3}{|c|}{ Simulation 2} & \multicolumn{3}{|c|}{ Simulation 3} \\
\hline & & \multirow{2}{*}{ Shock } & \multicolumn{2}{|c|}{ Change } & \multirow{2}{*}{ Shock } & \multicolumn{2}{|c|}{ Change } & \multirow{2}{*}{ Shock } & \multicolumn{2}{|c|}{ Change } \\
\hline & & & Value & $\%$ & & Value & $\%$ & & Value & $\%$ \\
\hline 1 Paddy & 113.74 & 0.00 & 5.31 & 4.67 & 11.38 & 11.38 & 10.00 & 11.38 & 11.38 & 10.00 \\
\hline 2 Wheat & 31.58 & 0.00 & 1.76 & 5.57 & 3.16 & 3.16 & 10.00 & 3.16 & 3.16 & 10.00 \\
\hline 3 Other grains \& crops & 347.33 & 0.00 & 17.41 & 5.01 & 34.73 & 34.73 & 10.00 & 34.73 & 34.73 & 10.00 \\
\hline 4 Livestock \& fishery & 212.41 & 0.00 & 10.12 & 4.76 & 0.00 & 12.52 & 5.89 & 0.00 & 25.41 & 11.96 \\
\hline 5 Forestry & 17.38 & 0.00 & 0.69 & 3.95 & 0.00 & 0.58 & 3.32 & 0.00 & 1.01 & 5.82 \\
\hline 6 Mining & 7.46 & 0.00 & 0.05 & 0.70 & 0.00 & 0.07 & 0.92 & 0.00 & .09 & 1.17 \\
\hline 7 Food pr & 98.09 & 0.00 & 3.89 & 3.97 & 0.00 & 3.76 & 83 & 00 & 9.19 & 9.37 \\
\hline 8 Other & 160.69 & 0.00 & 2.15 & 1.34 & 0.00 & 2.74 & 70 & 00 & 18 & 5.71 \\
\hline 9 Public & 34.06 & 0.00 & 0.48 & 1.40 & 0.00 & 0.68 & 2.01 & 0.00 & 3.76 & 11.02 \\
\hline 10 const & 259.17 & 0.00 & 1.54 & 0.60 & 0.00 & 1.55 & 50 & 00 & 4.72 & 1.82 \\
\hline 11 Servi & 12 & 0.00 & 24.79 & 2.94 & 0.00 & 26.85 & 18 & 00 & 48.73 & 5.78 \\
\hline tal Domestic & 2126.03 & 0.00 & 68.19 & 3.21 & 49.27 & 98.02 & 4.61 & 49.27 & 151.36 & 7.12 \\
\hline 12 Labor & 505.03 & 0.00 & 18.19 & 3,60 & 0.00 & 32.62 & 6.46 & 0.00 & 41.19 & 8.16 \\
\hline 13 & 6.03 & 00 & 17.26 & 3.10 & 0.00 & 31.37 & 4 & 0 & 48.04 & 8.64 \\
\hline $14 \mathrm{La}$ & 2.48 & 0.00 & 9.57 & 4.97 & 0.00 & 15.05 & 7.82 & 0.00 & 20.05 & 10.42 \\
\hline tal Factor I & 1253.54 & 0.00 & 45.02 & 3.59 & 0.00 & 79.04 & 6.31 & 0.00 & 109.28 & 8.72 \\
\hline 16 Urba & 1.50 & 0.00 & 0.04 & 2.79 & 0.00 & 0.08 & 5.08 & 00 & 0.11 & 7.06 \\
\hline 17 & 6. & 0.00 & 0.21 & 3.12 & 0.00 & 0.40 & 95 & 00 & 51 & 61 \\
\hline 18 Urban & 2.26 & 0.00 & 0.07 & 3.16 & 0.00 & 0.13 & 5.92 & 00 & 18 & 7.78 \\
\hline 19 Urbar & 12 & 0.00 & 0.36 & 2.90 & 0.00 & 0.66 & 5.35 & 00 & 91 & 7.32 \\
\hline 20 Urban & 137.73 & 0.00 & 3.32 & 2.41 & 0.00 & 6.53 & 4.74 & 00 & 63 & 5.54 \\
\hline 21 Urban & 14 & 0.00 & 3.44 & 2.34 & 0.00 & 6.58 & 48 & 00 & 13 & 5.46 \\
\hline 22 Urban r & 12.96 & 0.00 & 0.38 & 2.96 & 0.00 & 0.71 & 5.46 & 0.00 & 0.97 & 7.50 \\
\hline 23 Urban r & & 0.00 & 0.83 & 2.44 & 0.00 & 1.55 & 4.58 & 00 & 05 & 6.05 \\
\hline & & 000 & 2.36 & 1.80 & 0.00 & 4.47 & 40 & 10 & 95 & 4.52 \\
\hline 25 & 0.68 & 0.29 & 0.29 & 41.99 & 0.00 & 0.04 & 5.14 & 0.29 & 0.29 & 41.99 \\
\hline 26 Rural la & 59.60 & 24.56 & 24.56 & 41.21 & 0.00 & 3.05 & 5.11 & 24.56 & 24.56 & 41.21 \\
\hline $27 \mathrm{r}$ & 12.02 & 4.71 & 4.71 & 39.15 & 0.00 & 0.62 & 5.19 & 4.71 & 4.71 & 39.15 \\
\hline 88 Pura & 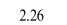 & 0.63 & 0.63 & 27.80 & 0.00 & 004 & 1.55 & 0.63 & 63 & 27.80 \\
\hline 29 Rural m & 97.67 & 7.88 & 7.88 & 8.07 & 0.00 & 5.31 & 5.44 & 7.88 & 88 & 8.07 \\
\hline 30 Rural & 35.38 & 2.35 & 2.35 & 6.63 & 0.00 & 1.83 & 5.18 & 2.35 & 2.35 & 6.63 \\
\hline & & 0.00 & 0.50 & 3.28 & 0.00 & 0.94 & 6.14 & 0.00 & 1.19 & 7.79 \\
\hline 32 Rura & 210 & 0.00 & 6.35 & 3.02 & 0.00 & 12.31 & 5.86 & 0.00 & 14.73 & 7.01 \\
\hline 33 Rural small-Others & 237.04 & 0.00 & 7.38 & 3.11 & 0.00 & 14.00 & 5.91 & 0.00 & 17.23 & 7.28 \\
\hline & 56 & 0.00 & 0.12 & 2.70 & 0.00 & 0.23 & 4.97 & 0.00 & 0.30 & 6.61 \\
\hline 35 Ruraln & 32 & 000 & 0.82 & 2.55 & 0.00 & 1.59 & 4.95 & 0.00 & 02 & 6.29 \\
\hline 36 Rural medium-Others & 63.33 & 0.00 & 1.79 & 2.83 & 0.00 & 3.44 & 5.42 & 0.00 & 4.36 & 6.88 \\
\hline 37 Rural large-KTM & 1.47 & -0.07 & -0.07 & -4.54 & 0.00 & 0.07 & 4.99 & -0.07 & -0.07 & -4.54 \\
\hline & & -2.37 & -2.37 & -8.65 & 0.00 & 1.63 & 5.96 & -2.37 & -2.37 & -8.65 \\
\hline 39 Rural large-Others & 20.99 & -1.24 & -1.24 & -5.89 & 0.00 & 0.97 & 4.61 & -1.24 & -1.24 & -5.89 \\
\hline tal Household Income & 1305.97 & 36.74 & 64.71 & 4.95 & 0.00 & 67.18 & 5.14 & 36.74 & 102.91 & 7.88 \\
\hline
\end{tabular}

simultaneously. In fact, land reform should be done in such a way that both reform measures work together to boost the productivity of Nepalese economy reducing poverty and inequality. Comparing between three policy scenarios given by three simulations, we clearly see that $10 \%$ productivity augmenting reform has higher impacts that redistributive reform and both reforms simultaneously (simulation 3) has the highest impacts among the three alternative policies.

Furthermore, table 5 shows the sector-wise and household-wise changes in production and income due to the implementation of three types of land reform policies. In simulation 1, the redistributive land reform policy creates shock on large, marginal and landless households. Since, large households in all three regions have beyond current ceiling land; implementation of redistributive land reform policy will bring them negative shock in their income while in case of landless and marginal households in all three regions, this type of land reform brings positive shock on their income. Simulation 2 in table 5 is the impact of $10 \%$ increase in agricultural production of crops. In this simulation, we see the shock in the production of paddy, wheat and other grains and crops. By the multiplier effect, this shock will bring positive changes in all sectors and households, mentionable are land input ( $7.82 \%$ increases), labor (6.46\% increases), total household income increases by $5.14 \%$. In simulation 3, we see that both types of shock are present and the impact in production and income is larger. This policy option is the best among three in terms of increasing both production and income.

The above mentioned policy alternatives of land reform increase household income, factor income and, sectoral production causing Nepalese economy to achieve higher economic growth rate. As the economy will grow and the distribution pattern changes, what may be the impact on poverty and inequality? The income of landless and marginal households will increases as the result of transfer of land ownership and it will help to reduce poverty and achieve equity. We have seen from simulation results that economy grows substantially. We present the results of inequality analysis before and after all three types of reform policies in table 6 .

Table 6. Change in Income Inequality Due to Land Reform

\begin{tabular}{lcccc}
\hline Inequality Measures & Baseline & Simulation 1 & Simulation 2 & Simulation 3 \\
\hline \multirow{2}{*}{ Gini Coefficient } & 0.31 & 0.25 & 0.31 & 0.25 \\
& $(0.07)$ & $(0.06)$ & $(0.07)$ & $(0.06)$ \\
Theil Index & 0.18 & 0.13 & 0.18 & 0.13 \\
& $(0.06)$ & $(0.05)$ & $(0.06)$ & $(0.05)$ \\
Coefficient of Variation & 0.55 & 0.45 & 0.55 & 0.46 \\
& $(0.11)$ & $(0.10)$ & $(0.11)$ & $(0.10)$ \\
\hline Source:
\end{tabular}

Source: Authors' estimation

Note: Standard error of estimate in ( ), calculated at $95 \%$ confidence interval.

Moreover, in the redistributive reform (simulation 1 and simulation 3), landless households will acquire redistributed land and they will not be landless anymore. Instead, they will fall in the category of marginal households. Similarly, the large households will lose their beyond ceiling land and fall in the category of medium households. Additionally, the decrease in income of large households is less than the 
increase in income of landless and marginal households resulting substantial increase in rural income, which evidences the importance of land reform in Nepal.

In baseline, Gini coefficient is 0.31 , Theil index is 0.18 and coefficient of variation is 0.55 (see table 6). As the result of implementation of redistributive land reform, inequality reduces in simulation 1 but in case of $10 \%$ productivity augmenting reform, inequality does not change. If both reforms are implemented together, inequality reduces as similar in the case of distributive reform policy.

\section{Conclusion}

Redistributive land reform increases income of poor households and reduces inequality. Increase in productivity of crop sectors due to reform has more impact on economy as it increases productivity of all sectors including income of all households keeping inequality unchanged. Furthermore, implementing both types of reforms simultaneously produce huge impact on Nepalese economy by gaining both equity and efficiency. Therefore, we recommend that both types of reform should be implemented simultaneously in Nepal to reduce poverty, inequality and to achieve pro-poor economic growth.

The process of land reform has been very slow in Nepal. One of the reasons is that people including politicians do not realize the potential gain from land reform. Furthermore, without any simulation, it is hard to know the quantitative effects. Therefore, we estimate the effects in this paper expecting great impact for implementation of the reform.

Though, Government of Nepal being unable to enforce comprehensive land reform, it is the top priority agenda of almost all of the political parties (ruling and opposition). Because of the lack of stable government for many years (almost for 22 years), this agenda could not be implemented properly. Once strong government is formed, there is feasibility of land reform.

However, in SAM model price is assumed constant and exogenous. This type of fixed price model does not capture the substitution effects. In addition, in SAM model, some sectors must be kept exogenous. This has disadvantage of over calculation of change in income, output and other variables. In contrary, computable general equilibrium (CGE) model assumes price as endogenous and captures the substitution effects. Moreover, in CGE model, all sectors are assumed endogenous; labor market is cleared and may give micro-economic consistent effects of policy. Therefore, to overcome the bottlenecks that arise in SAM framework, we suggest using computable general equilibrium (CGE) modeling framework to study the impact of alternative policy scenarios of land reform in Nepal, which is also the topic for our further research.

\section{References}

[1] Adhikari, C. B. and Bjorndal, T. "Can Land Reform be an Effective Approach to Alleviate Poverty in Nepal," Working Paper no 30/09. Institution for Research in Economics and Business Administration. Bergen 2009.

[2] Adhikari, J. Land Reform in Nepal Problems and Prospects. Action Aid Nepal, 2008.

[3] Central Bureau of Statistics. Nepal Living Standard Survey III Dataset. Kathmandu: Central Bureau of Statistics, 2011.

[4] Central Bureau of Statistics. Poverty in Nepal. Kathmandu: Central Bureau of Statistics, 2011.

[5] Community Self-Reliance Centre. Land and Land Tenure Security in Nepal- A Country Report. Kathmandu, 2003.

[6] Lipton, M. Land Reform in Developing Countries: Property Rights and Property Wrongs. London: Rutledge, 2010.

[7] Ministry of Finance. Economic Survey. Kathmandu: Government of Nepal, 2013.

[8] Nepal Law Commission. Lands Related Act 1964. Kathmandu: Government of Nepal, 2012.

[9] Paudel, D. B. and Saito, K. "An Evaluation of Land Reform in Nepal-Simulation Based Approach," The Japanese Journal of Rural Economics, Special Issue, 2012, pp. 418-425.

[10] Paudel, D. B. and Saito, K. "Does Land Reform Increase Efficiency in a Developing Economy? A Case from Nepal," Department of Agricultural and Resource Economics Working Paper Series 13-E-001. The University of Tokyo, 2013.

[11] Paudel, D. B. and Saito, K. "Estimation of Nepal Social Accounting Matrix for 2010/11 and Its Application for Policy Studies," Department of Agricultural and Resource Economics Working Paper Series 13-E-002. The University of Tokyo, 2013.

[12] Regmi, M. Land Ownership in Nepal. Delhi: Adroit Publishers, 1977.

[13] Sadoulet, E. and de Janvry, A. Quantitative Development Policy Analysis. Baltimore: Johns Hopkins University Press, 1995.

[14] The World Bank. World Development Indicators 2013. Washington D.C.: The World Bank, 2013. 